\title{
Problemy społeczne gospodarki odpadami
}

\author{
Wiktoria SOBCZYK ${ }^{1)}$, Anna KOWALSKA ${ }^{2)}$
}

\footnotetext{
${ }^{1)}$ prof. dr hab. inż.; Katedra Inżynierii Środowiska, AGH Akademia Górniczo-Hutnicza, 30-059 Kraków, Al. Mickiewicza 30, Polska; email: sobczyk@agh.edu.pl

2) dr inż.; Instytut Matematyczno-Przyrodniczy, Zakład Ochrony Środowiska, Państwowa Wyższa Szkoła Zawodowa w Tarnowie,

33-100 Tarnów, ul. Mickiewicza 8, Polska; email: annakowalska333@op.pl
}

http://doi.org/10.29227/IM-2020-01-10

Submission date: $21-12-2019$ | Review date: 22-01-2020

\begin{abstract}
Odpady stanowią problem $w$ skali lokalnej i globalnej. Ich masa jest niemalże równa masie produkowanych przez człowieka towarów. Rośnie również ich różnorodność. W pracy wykorzystano metody studiów literaturowych oraz dokumentacyjną. Wskazano na niebezpieczeństwo pozbywania się odpadów problematycznych w strumieniu odpadów komunalnych. Bogaty materiał faktograficzny wykazał, że problem braku kultury ekologicznej dotyczy nie tylko Polaków, ale także społeczeństw innych krajów. Zaśmiecone ulice, skwery, parkingi, przystanki to powszechny widok dosłownie wszędzie. Jak temu zaradzić?

Sposobem najprostszym, a jednocześnie najtrudniejszym, jest edukacja ekologiczna społeczeństwa. Do wszystkich grup wiekowych kierowane są kampanie edukacyjne dotyczace zasad segregacji odpadów, lokalizacji punktów selektywnej zbiórki odpadów, problematyki odpadów niebezpiecznych. Najwyższy czas wyzbyć się cech ignorancji ekologicznej. Nie czyńmy Ziemi tego, co nam jest niemite.
\end{abstract}

Słowa kluczowe: gospodarka odpadami, edukacja ekologiczna, etyka ekologiczna

\section{Wstęp}

Rozwój gospodarczy świata jest związany z problematyką surowcową oraz ochroną środowiska, w tym ochroną przed niekorzystnym oddziaływaniem odpadów na otoczenie. Działania w kierunku racjonalnego wykorzystania odpadów, nadania im nowej formy oraz zredukowania ich masy prowadzone są na całym świecie. Przez wiele lat podstawową formą unieszkodliwiania odpadów było gromadzenie ich na składowiskach. Duże zmiany w gospodarce odpadami rozpoczęły się pod koniec XX w. Przy postępowaniu z odpadami zaczęła obowiązywać hierarchia działań, obejmująca w kolejności: zapobieganie powstawaniu odpadów, minimalizację ilości odpadów, wykorzystanie odpadów (recykling lub odzysk) oraz unieszkodliwianie ze składowaniem włącznie. Wzrost świadomości społeczeństwa co do zagrożeń powodowanych przez odpady wymusił rozpoczęcie budowy wielu instalacji gospodarki odpadami. Systematycznie zamykane są stare składowiska, a budowane nowe, o zminimalizowanym wpływie na środowisko. Odchodzi się od systemu, w którym jedyną metodą unieszkodliwiania odpadów jest składowanie, na rzecz sytemu złożonego z kilku elementów: zbiórki surowców wtórnych, sortowania, kompostowania i termicznego przekształcania odpadów. Dopiero w latach dziewięćdziesiątych XX w. sformułowano w Polsce pierwsze przepisy prawne regulujące gospodarkę odpadami. Stan prawny uległ zmianie w związku z dostosowaniem polskiego prawa do norm obowiązujących w Unii Europejskiej. Już 15 lipca 1975 roku UE ustaliła podstawowe kierunki działań w zakresie gospodarki odpadami (dyrektywa 75/442/EWG kilkakrotnie nowelizowana). Do działań tych zaliczono: ustanowienie ogólnych zasad kontroli usuwania odpadów w skali krajowej, przyjęcie zasady minimalizacji powstawania odpadów, wprowadzanie czystych technologii, szerokie zastosowanie recyklingu, wykorzystywanie odpadów jako źródła energii.
Odpady komunalne stanowią coraz większy problem zarówno ekologiczny, dotyczący ich negatywnego oddziaływania na wszelkie elementy środowiska przyrodniczego, jak i gospodarczy, związany ze zbiórką, transportem oraz unieszkodliwianiem. Według najnowszych danych GUS w 2017 r. w Polsce zebranych zostało $12 \mathrm{mln}$ ton odpadów komunalnych, o 5\% więcej niż w roku poprzednim [https://www. forbes.pl/gospodarka/odpady]. Zdecydowanie najszybciej wzrasta masa opakowań jednorazowych.

We wszystkich gminach w Polsce funkcjonuje system zbiórki surowców wtórnych, przyczyniający się do oszczędzania surowców naturalnych i zmniejszający strumień odpadów, które muszą być poddane unieszkodliwianiu. Niestety, odpady wywożone na dzikie wysypiska na pola, do rowów, do lasów są ciągle plagą w naszym kraju. Władze gmin starają się temu zapobiec przez instalowanie monitoringu najczęściej uczęszczanych szlaków turystycznych oraz poprzez edukację społeczeństwa [www.ekoportal.gov.pl].

Zmieniające się przepisy ustaw środowiskowych i odpadowych, a także surowe dyrektywy unijne wymuszają na naszym społeczeństwie radykalną zmianę postaw wobec środowiska naturalnego. Przykładem następujących obecnie dynamicznych zmian jest znowelizowana Ustawa o utrzymaniu porządku i czystości w gminach, która zobowiązuje podmioty samorządowe do wdrożenia nowych rozwiązań w zakresie gospodarki odpadami, które $\mathrm{w}$ rezultacie doprowadzą do redukcji masy biodegradowalnych odpadów komunalnych składowanych na wysypiskach o 65\% w 2020 roku w stosunku do roku 1995. Niedostosowanie się do powyższych przepisów, o których stanowi również Dyrektywa 1999/31/EC, skutkować będzie nakładaniem kar pieniężnych na gminy [Dyrektywa Rady 1999]. 


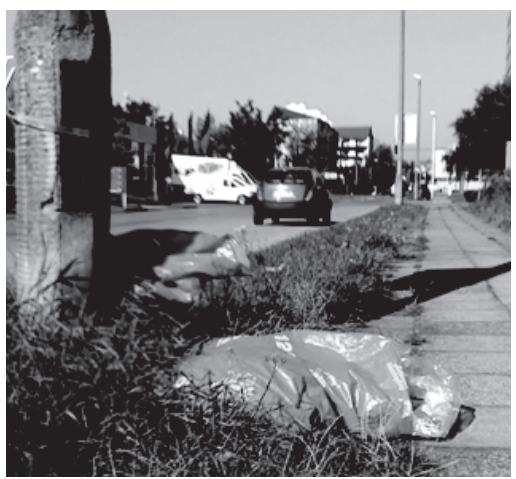

Fig. 1. Abandoned waste bags at the street curb [photo W. Sobczyk] Fig. 1. Porzucone worki z odpadami przy krawężniku ulicy [fot. W. Sobczyk]

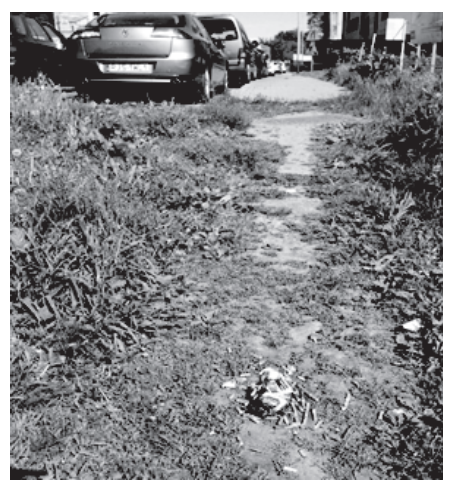

Fig. 2. Cigarette butts thrown out of the car [photo W. Sobczyk] Fig. 2. Niedopałki papierosów wyrzucone z samochodu [fot. W. Sobczyk]

Odpady stanowią problem w skali globalnej. Ich ilość jest niemalże równa ilości produkowanych przez człowieka towarów. Rośnie również ich różnorodność. Bardzo ważnym elementem gospodarki odpadami jest uzyskanie akceptacji społecznej zarówno dla lokalizacji obiektów unieszkodliwiania i utylizacji odpadów, jak i do wdrażania nowych rozwiązań. Negatywne nastawienie społeczeństwa wynika głównie z nieprzyjemnych doświadczeń związanych z eksploatacją składowisk w przeszłości, a także brakiem podstawowej wiedzy w zakresie ochrony środowiska, która niesie ze sobą lęk przed nieznanym. Brak świadomości społecznej skutkuje odrzuceniem wielu inwestycji już na etapie konsultacji społecznych [Sobczyk 2016]. Nasza wiedza w zakresie ekologii jest niewystarczająca, toteż udział społeczeństwa $\mathrm{w}$ tworzeniu lepszego jutra jest bardzo ograniczony. Czas to zmienić.

\section{Duże akcje edukacyjne}

Kampanie edukacyjne są skierowane do wszystkich grup wiekowych. Dotyczą one zasad segregacji odpadów, lokalizacji punktów selektywnej zbiórki poszczególnych rodzajów odpadów, problematyki odpadów niebezpiecznych, szkodliwości spalania odpadów poza specjalnymi instalacjami. Edukacja ekologiczna prowadzona na poziomie krajowym to szansa dotarcia do najszerszej grupy odbiorców. Państwo jako podmiot ma nieograniczone możliwości wpływu na postępowanie obywateli. Podatki i bodźce finansowe, regulacje prawne (np. nakazujące gminom organizowanie kampanii informacyjno-edukacyjnych w zakresie gospodarki odpadami).

Od wielu lat Ministerstwo Środowiska prowadzi kampanię „Nasze Śmieci”. Aktywne są organizacje pozarządowe:
LOP „Śmieć i My”, „Zielone Karpaty = Czyste Karpaty” i „Osobiście Segreguję". Kontrowersyjną akcją informacyjno-edukacyjną „Kochasz dzieci, nie pal śmieci” jest kampania organizowana przez Fundację „Arka”.

Także podmioty gospodarcze podejmują cenne inicjatywy. Przykładami prowadzonych w Krakowie dobrych praktyk są kampanie ekologiczne: „Elektryczne Śmieci”, „Czysty Kraków - lepsze życie”, „Segregując śmieci, dbasz o przyszłość dzieci”, „Góra śmieci Kraków szpeci”, „Naturalnie, że EKO-Kraków”.

Edukacja najmłodszych to najlepsza inwestycja w przyszłość. Miejskie Przedsiębiorstwo Oczyszczania w Krakowie organizuje warsztaty dla młodzieży szkolnej „Od segregacji nie ma wakacji”. W Centrum Ekologicznych Barycz od kilkunastu lat funkcjonuje ścieżka ekologiczna. Dla starszych dzieci i młodzieży przygotowano ścieżkę edukacyjną na składowisku, w kompostowni, w sortowni. Przykładem cennej akcji edukacyjnej, skierowanej do szkół, jest „Kino za baterie”. Natomiast edukacja dorosłych realizowana jest poprzez „Elektrobrygadę na telefon”.

Skoro funkcjonuje tak wiele inicjatyw ekologicznych, to $\mathrm{w}$ naszym kraju powinno być bardzo czysto. A jaka jest rzeczywistość? Polska jest krajem, którego mieszkańcy lubią bałagan, śmiecenie i brud. To powszechny obrazek dosłownie wszędzie. Ulice, chodniki, skwery, parkingi, przystanki wszędzie jest mnóstwo odpadów z papieru, plastiku, szkła, niedopałków. Polacy śmiecą na każdym kroku.

Nasze miasta są brudne i zaniedbane, co jest oznaką braku elementarnej kultury społeczeństwa. Ulice, chodniki, trawniki i pobocza są zaśmiecone. Obserwujemy dewastację koszy na odpady. Czy można niszczyć nasze wspólne dobro?! Ludzie 

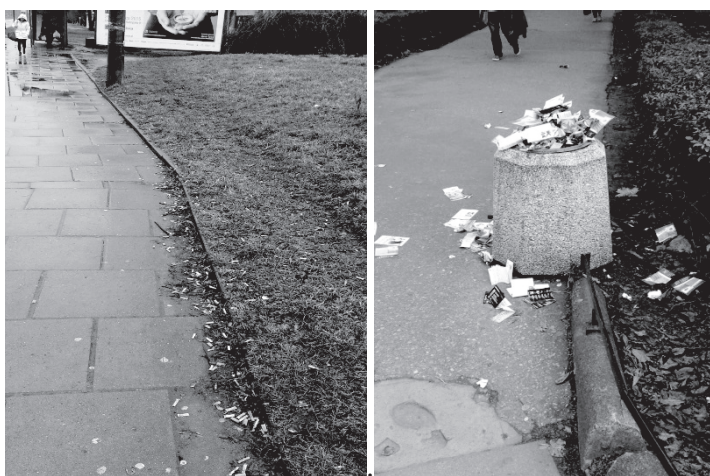

Fig. 3. Littering around bus stops [photo W. Sobczyk]

Fig. 3. Zaśmiecone okolice przystanków autobusowych [fot. W. Sobczyk]

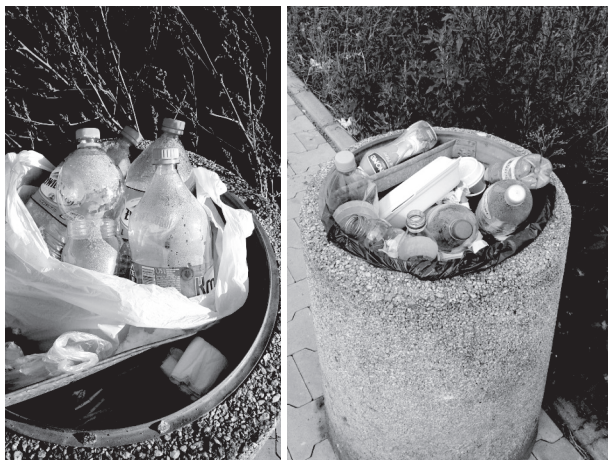

Fig. 4. Overfilled containers for waste - the effect of ignorance the rules of handling packaging waste [photo W. Sobczyk]

Fig. 4. Przepełnione kontenery na odpady - efekt nieznajomości zasad postępowania z odpadami opakowaniowymi [fot. W. Sobczyk]

porzucają worki ze śmieciami w parkach, pod drzewami, w zaroślach, przy krawężnikach ulic (fig. 1).

Karygodnym obrazkiem, ilustrującym zachowanie kierowców w okolicach miejsc parkowania samochodów, są sterty opakowań po artykułach spożywczych, po papierosach (fig. 2), napojach. Brak kultury, brak dbałości o estetykę otoczenia to nasze powszechne grzechy.

Kolejnym przykładem są zaśmiecone przystanki komunikacji miejskiej. Okolice przystanków to śmietniska pełne niedopałków papierosów, których nikt nie sprząta. Plagą przystanków są roznosiciele ulotek, promocja napojów itp. (fig. 3). Mimo że na przystankach zawsze znajdują się kosze na odpady, ludzie ich nie zauważają. Wygodniej jest wyrzucić odpad na trawnik, mimo że kosz jest metr, dwa dalej. Ludzie porzucają nawet całe worki śmieci przy przystankach.

Wszyscy miłośnicy zwierząt domowych wiedzą, że psie nieczystości są również odpadami kłopotliwymi. Przepisy mówią, że za pozostawienie psich odchodów na trawniku lub chodniku grozi kara grzywny do 500 zł. Po pupilkach należy sprzątać, więc sprzątajmy i odchody wyrzucajmy do specjalnie do tego przeznaczonych koszy lub do koszy na odpady zmieszane.

Nasze miasta są zaśmiecone nie tylko dlatego, że mieszkańcy nie dbają o czystość. Także dlatego, że brakuje koszy na śmieci. Służby oczyszczania nie nadążają z opróżnianiem kontenerów. Czemu? Ponieważ nasze społeczeństwo nie zna podstawowych zasad postępowania z odpadami. Dla przykładu: plastikowe pojemniki po napojach należy zgnieść, wów- czas kosz zapełni się po trzech dniach, a nie w ciągu jednego popołudnia (fig. 4). Służby przyjadą rzadziej, spalą mniej paliwa, będzie mniej korków ulicznych, mniejszy hałas itd.

\section{Zakończenie}

Nieprzestrzeganie przepisów powinno być surowo karane. Pozwoli to ograniczyć skalę negatywnego zjawiska powszechnego śmiecenia, powstawania "dzikich wysypisk”, samowolnego spalania odpadów, postępowania niezgodnego z deklaracją. Wyniki analiz świadomości ekologicznej pokazują, iż poziom wiedzy i odpowiedzialności Polaków za środowisko naturalne, mimo iż z roku na rok wzrasta, wciąż pozostaje na niezadowalającym poziomie. Jako społeczeństwo jesteśmy zbyt mało zaangażowani w podejmowanie inicjatyw oraz działań prośrodowiskowych, zarówno w sferze życia osobistego, jak i publicznej [Sobczyk, Biedrawa, Kowalska 2011].

Nic nie zastąpi edukacji środowiskowej, która ma fundamentalne znaczenie dla ochrony środowiska przed degradacją oraz dla zachowania go dla przyszłych pokoleń [Pawul, Sobczyk 2011]. Uporczywe powtarzanie informacji i przypominanie zasad to najskuteczniejszy sposób, by podnieść poziom świadomości ekologicznej. Uczmy się właściwego postępowania od innych, lepszych. Kształtujmy naszą wrażliwość ekologiczną. Dbajmy o czystość naszego otoczenia, podobnie jak dbamy o porządek w naszych domach. Nie ustawajmy w wysiłkach wychowywania społeczeństwa. Rok 2014 był ostatni w dekadzie poświęconej edukacji ekologicznej na świecie. Co będzie dalej? 


\section{Literatura - References}

1. Dyrektywa Rady 1999/31/WE z dnia 26 kwietnia 1999 r. Dyrektywa Rady w sprawie składowania odpadów.

2. https://www.forbes.pl/gospodarka/odpady-komunalne-i-wysypiska-smieci-w-2017-r-w-polsce/j48mtvg (dostęp 7 IX 2019).

3. Pawul M., Sobczyk W.: Edukacja ekologiczna w zakresie gospodarki odpadami jako narzędzie realizacji zrównoważonego rozwoju, „Problems of sustainable development” 2011, vol. 6, no 1, 147-156.

4. Sobczyk W.: Aspekty społeczne i środowiskowe gospodarki odpadami. Wydawnictwo Naukowe AGH, 2016, ss. 218.

5. Sobczyk W., Biedrawa A., Kowalska A.: Management of municipal waste in national parks of Europe. Teka Komisji Ochrony i Kształtowania Środowiska Przyrodniczego 2011, vol. 8, s. 159-168.

6. $\quad$ www.ekoportal.gov.pl (dostęp 7 IX 2019).

\section{Social Problems of Waste Management}

Waste is a problem on a local and global scale. Their mass is almost equal to the mass of man-made goods. Their diversity is also growing. The work uses literature and documentary methods. The danger of getting rid of problematic waste in the municipal waste stream was pointed out. Rich factographic material has shown that the problem of the lack of ecological culture applies not only to Poles, but also the societies of other countries. Littered streets, squares, parking lots, stops are a common sight everywhere. How do we fix this? The ecological education of society is the most simple and the most difficult method. Educational campaigns concerning the rules of waste segregation, location of selective waste collection points, and hazardous waste issues are addressed to all age groups. It's time to get rid of the features of ecological ignorance. Do not let us do the Earth, what is unpleasant to us.

Keywords: waste management, ecological education, ecological ethics 